\title{
GC-MS Analysis and Anti-Microbial Activities of Volatile Oil of Nardostachys jatamansi D.C. Rhizomes Obtained from Haridwar Region, Uttrakhand
}

\author{
Vijender Singh ${ }^{1}$, Neha Rana ${ }^{* 2}$, Mohd Ali ${ }^{1}$
}

\section{Vijender Singh ${ }^{1}$, Neha Rana $^{* 2}$ Mohd Ali ${ }^{1}$}

'Sharda School of pharmacy, Greater Noida, Uttar Pradesh, INDIA.

${ }^{2}$ Raj Kumar Goel Institute of Technology (Pharmacy), Ghaziabad, Ex Dean of

Jamia Hamdard, New Delhi, INDIA.

Correspondence

\section{Neha Rana}

Pharmaceutical Chemistry, Raj Kumar Goel Institute of Technology (Pharmacy), Ghaziabad, 201004, INDIA.

Phone No: 9716088185

E mail Id: nehaa_rana@yahoo.co.in

History

- Submission Date: 10-11-2017.

- Review completed: 30-11-2017;

- Accepted Date: 18-12-2017

DOI: 10.5530/pj.2018.2.40

Article Available online

http://www.phcogj.com/v10/i2

Copyright

(C) 2018 Phcog.Net. This is an openaccess article distributed under the terms of the Creative Commons Attribution 4.0 International license.

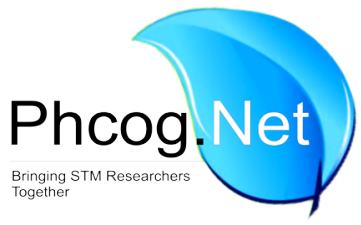

\section{ABSTRACT}

The Rhizomes of Nardostachys jatamansi D.C (Family Valerianceae) were collected from Haridwar, Uttarakhand. Aim: To identify the various volatile constituents of Nardostachys jatamansi D. C. Rhizomes and evaluation of antimicrobial activity. Method: The essential oil was collected by hydro distillation and analyzed by Gas Chromatography (GC) and Gas Chromatography-Mass Spectroscopy (GC-MS). Volatile oil constituents, antimicrobial potential of Nardostachys jatamansi D. C. Rhizomes have been studied using different concentrations of the volatile oil against some micro-organisms. Results: A total of 10 compounds were identified from their fragmentation pattern. The Identified compounds were Calarene $(20.4 \%)$, Vardiflorene (12.3\%), $\alpha$-Panasinsen $(9.7 \%), \alpha$-Santalene $(4.6 \%), \gamma$-Himachelene (17.1\%), Jatamansone (7\%), lonol 4 (9.9\%), 2,2,7,7-Tetramethyl tricyclo[6,2,1,0 (1,6)] undec-4-ene 3-one $(1.7 \%)$, Epiglobulol (1.9\%) and Resibufogenin (8.4\%). Among them major constituents characterized was Calarene $(20.4 \%)$ and followed by $\gamma$-Himachelene $(17.1 \%)$ and Vardiflorene $(12.3 \%)$. The volatile oil showed significant activity against all tested microorganisms. The maximum antibacterial activity was shown with $1 \% \mathrm{v} / \mathrm{v}$ of volatile oil on Staphylococcus aureus $(12.8 \mathrm{~mm}$ ) followed by Escherichia coli $(12.4 \mathrm{~mm})$, whereas maximum anti-fungal activity was shown by $1 \% \mathrm{v} / \mathrm{v}$ of volatile oil on Candida albicans $(12.3 \mathrm{~mm})$ followed by Aspergillus niger (11.9 mm). Conclusion: All identified constituents showed antibacterial activity and antifungal activity. Thus, the constituents should be further identified and analyzed by other spectrosopical techniques.

Key words: Nardostachys jatamansi DC, GC GC-MS analysis, Volatile oil, Hydro distillation, Anti-microbial activity.

\section{INTRODUCTION}

Nardostachys jatamansi D.C. (f. Valerianaceae), commonly known as Indian Nard, spikenard or balchar, is a 10-60 $\mathrm{cm}$ high perennial herb found in alpine Himalayas at an attitude of 3700-5700 m. ${ }^{1,2}$ Bornyl acetate, jatamansic acid, jatamansinol, jatanols $\mathrm{A}$ and B, nardol, jatamansone, jatamansin, $\alpha$-humulene, cubebol, cis- $\beta$-farnesene, ledol, ledene epoxide, and nordostachone components of the volatile oil have been reported from rhizome. The volatile oil of a Chinese species, $N$. grandiflora, contained nardostachnol, aristol-9-ene, aristol-(10) ene, $\beta$-maaliene and 1, 2, 9, 10 -tetraelehydroaristolene. Major sesquiterpenes in Nardostachys jatamansi are Jatamansone and valerone, while rests are Jatamansol, jatamansic acid, dihydrojatamansin, nardosatchone. Some minor contributors like jatamol A and B, nardosinone, spirojatamol, jatamansinone, orseolol, orselone, valeranal, serselinnardostachyins, seychelane, seychellene, coumarin and xanthogalin have also been reported as well as alkaloids and actinidines have been reported. ${ }^{3,4,5,6,7,8,9,10}$

The Rhizomes have emmenogogue, stimulant, and diuretic and deobstruent properties and are also prescribed in the indigenous system of medicine for the treatment of hysteria, epilepsy, chest pain, convulsions and palpitation of the heart. Its oil promotes growth and blackness of the hair. ${ }^{2}$ Spikenard oil possesses antiarrhythmic activity with possible therapeutic usefulness for auricular flutter; it is less effective than quinedine but has advantage of being less toxic. ${ }^{2,3}$ Its Rhizomes have showed anti-microbial activity against bacteria and fungi. ${ }^{10,11,12}$

\section{MATERIAL AND METHODS}

\section{Plant material}

The air-dried Rhizomes of $N$. jatamansi were obtained from Haridwar, Uttrakhand, India. The plant material was identified by Dr. Sunita Garg of NISCAIR, New Delhi and the voucher specimen was submitted their for future reference Ref.No. NISCAIR/ RHMD/ Consult/ 2015/ 2855-48-3.

Cite this article: Singh V, Rana N, Ali M. GC-MS Analysis and Anti-Microbial Activities of Volatile Oil of Nardostachys jatamansi D.C. Rhizomes Obtained from Haridwar Region, Uttrakhand. Pharmacog J. 2018;10(2):230-4. 


\section{Isolation of volatile oil}

The air-dried Rhizomes of Nardostachys jatamansi (500 g.) were hydrodistilled according to the method recommended in British Pharmacopoeia, 2009 Figure $4 .{ }^{13}$ The light pale-yellow oil so obtained was dried over anhydrous sodium sulphate and stored at $4^{\circ} \mathrm{C}$ in the dark. The yield was $2 \%$ based on fresh weight of sample.

\section{GC Analysis}

Analytical GC was carried out on a Varian 3300 gas chromatograph fitted with a silicon DB-I capillary column $(30 \mathrm{~m} \times 0.25 \mathrm{~m})$, film thickness $0.25 \mu \mathrm{m}$., carrier gas Nitrogen, flow rate $1.5 \mathrm{ml} / \mathrm{min}$., split mode, temperature programmed $80-250^{\circ} \mathrm{C}$ at $4^{\circ} \mathrm{C} / \mathrm{min}$. Injector temperature and detector temperature were $250^{\circ} \mathrm{C}$ and $300^{\circ} \mathrm{C}$ respectively. Detector used was FID. Injection volume for all samples was $0.1 \mu l$.

\section{GC-MS Analysis}

Analytical GC-MS was carried out on a QP2000 instrument at $70 \mathrm{eV}$ and $250^{\circ} \mathrm{C}$. GC column Ulbon HR -1 fused silica capillary $0.25 \mathrm{~mm} \times 50 \mathrm{~m}$ with film thickness $0.25 \mu$. The initial temperature was $100{ }^{\circ} \mathrm{C}$ for $6 \mathrm{~min}$. and then heated at a rate of $10^{\circ} \mathrm{C}$ per min to $250^{\circ} \mathrm{C}$. Carrier gas Helium, flow rate $2 \mathrm{ml} / \mathrm{min}$, detector used was FID.

\section{Identification}

The volatile components were identified by comparing their retention indices of GC chromatograph with those of literature. Further identification was done by GC-MS. The fragmentation patterns of mass spectra were compared with those of the spectrometer data base using the NBS $54 \mathrm{AL}$ and Wiley L-built libraries and with those reported in the literature. ${ }^{14,15,16,17,18,19,20}$ Many constituents were identified by comparing their retention indices with those of authentic standards available in the author's laboratory (Table 1 and 2).

\section{Anti-microbial activity}

\section{Preparation of sample}

The volatile oil $(0.1 \% \mathrm{v} / \mathrm{v}, 0.5 \% \mathrm{v} / \mathrm{v}, 1 \% \mathrm{v} / \mathrm{v})$ were dissolved in dimethyl sulfoxide (DMSO) for anti-microbial activity.

\section{Preparation of standard drug solutions}

Chloramphenicol and Ketoconazole were used as standard solutions for comparison of anti-bacterial and anti-fungal activities. Both the standard drugs were taken in DMSO. The concentration of both standard drugs solution was $10 \mathrm{mg}$. / $\mathrm{ml}$.

\section{Anti-Microbial activity}

The antimicrobial activities of volatile oil and dried alcoholic extract of dried Rhizomes of $N$. jatamansi were performed in the Department of Microbiology, School of Pharmacy, Sharda University, Greater Noida. The identification of microbial strains was based on morphological, cultural and biochemical tests. The in-vitro antimicrobial activity of various oil concentrations of the $N$. jatamansi Rhizomes were studied by the cup plate method. ${ }^{21,22,23}$ Against various microorganisms mentioned in the (Table 3 and Figure 3).

Chloramphenicol and Ketoconazole were used as standard and the activity of each concentration was compared with corresponding concentration of standard drugs. The plates were incubated at $37 \pm 2{ }^{\circ} \mathrm{C}$ for antibacterial activity and $25 \pm 2^{\circ} \mathrm{C}$ for anti-fungal activity, after $48 \mathrm{~h}$ of incubation. The Petri dishes were taken out from the incubator and the anti-microbial activity of different concentrations of oil of $N$. jatamansi Rhizomes were compared by measuring the diameter of the zone of inhibition (Tables 3 and Figure 3).
The control DMSO showed no inhibition of growth, while all the concentration of oil were effective against E. coli and S.aureus when compared with chloramphenicol and Ketoconazole. The maximum activity was observed with $1 \% \mathrm{v} / \mathrm{v}$ concentration of volatile oil of N. jatamansi Rhizomes.

\section{Statistical Analysis}

All the readings were taken in triplicate and statistical analysis were conducted using one-way analyses of variance (ANOVA). The results were represented as means of triplicate readings \pm standard deviations (SD). P values $<0.05$ were considered significant.

\section{RESULTS}

The volatile constituents have been identified successfully by using GC and GC- MS techniques. The essential oil obtained from N. Jatamansi roots is slightly viscous and pale yellowish green with strong odour. The name of volatile constituent, percentage (\%), retention index (RI), molecular formula, molecular weight and mass fragmentation index are given in Table 1 and 2 respectively. For antibacterial activity Test Organism i.e. Staphylococcus aureus, Escherichia coli, Candida albicans and Asperigillus niger, zone of inhibition ( $\mathrm{mm}$ ) for three different concentration of volatile oil i.e. $0.1 \%, 0.5 \%$ and $1.0 \%$ and two standard drugs i.e. Chloramphenicol and Ketoconazole is given in Table 3 and represented graphically in Figure 3. Molecular structures and GC-MS spectra for the identified constituents are shown in Figure 1 and 2 respectively.

The 10 Identified compounds were Calarene (20.4\%), Vardiflorene (12.3\%), $\alpha$ - Panasinsen (9.7\%), $\alpha$ - Santalene (4.6\%), $\gamma$-Himachelene (17.1\%), Jatamansone (7\%), Ionol 4 (9.9\%), 2,2,7,7- Tetramethyl tricyclo $[6,2,1,0(1,6)]$ undec-4-ene 3-one (1.7\%), Epiglobulol (1.9\%) and Resibufogenin $(8.4 \%)$.

The antibacterial activity observed was summarized in Table 3 . The Volatile oil concentrations $0.1 \%, 0.5 \%$ and $1 \% \mathrm{v} / \mathrm{v}$ were found to be effective against Staphylococcus aureus and Escherichia coli at inhibition zone of about $12.8 \mathrm{~mm}$ and $12.4 \mathrm{~mm}$ respectively which are comparable with Chloramphenicol having concentration of $0.1 \mathrm{mg} / \mathrm{ml}$. The anti-fungal activity observed was summarized in Table 3 . The volatile oil concentrations $0.1 \%, 0.5 \%$ and $1 \% \mathrm{v} / \mathrm{v}$ of volatile oil were found to be effective against Candida albicans and Aspergillus niger at inhibition zone of about $12.3 \mathrm{~mm}$ and $11.9 \mathrm{~mm}$ respectively which are comparable with Ketoconazole having concentration of $0.1 \mathrm{mg} / \mathrm{ml}$.

\section{DISCUSSION}

Recently many volatile oils were found to be useful in the treatment of various diseases. The GC and GC-MS analytical techniques were very useful technique in qualitative and quantitative estimation of volatile constituents. The present aim of the study is to identify various volatile constituents and to evaluate their antimicrobial activity.

The \% yield of volatile oil observed is $0.5 \%$. Seven Sesquiterpenes (70\%) were found, out of which five were hydrocarbons i.e. Calarene (20.4\%), Vardiflorene (12.3\%), $\alpha$ - Panasinsen (9.7\%), $\alpha$-Santalene (4.6\%), $\gamma$-Himachelene (17.1\%), one is ketonic i.e. Jatamansone $(7 \%)$ and one is alcoholic i.e. Epiglobulol (1.9\%); one Ttriterpene (10\%) is observed i.e. Resibufogenin $(8.4 \%)$; among others two $(20 \%)$ were found i.e Ionol 4 (9.9\%), 2,2,7,7- Tetramethyl tricyclo[6,2,1,0 (1,6)] undec-4-ene 3-one (1.7\%) (Table 1 and 2).

Antimicrobial activities of different concentrations of volatile oil of N. jatamansi Rhizomes obtained from Dist. Haridwar, Uttrakhand, India (Table 3). The maximum antibacterial activity was shown with $1 \% \mathrm{v} / \mathrm{v}$ of volatile oil of jatamansi Rhizomes on Staphylococcus aureus $(12.8 \mathrm{~mm})$ followed by Escherichia coli $(12.4 \mathrm{~mm})$, whereas maximum anti-fungal 
<smiles>CC1CCC=C2CCC3C(C)C3(C)C21C</smiles>

(1) Calarene

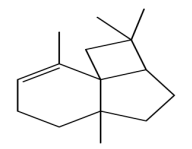

(3) a-Panasinsen<smiles>CC(C)=CCCC1(C)CCCC1(C)C</smiles>

(4) a-Santalene<smiles>CC1=CCC(C)(C)C2CCCC12</smiles>

(5) $\gamma$-Himachalene<smiles>CC(C)C1CCC2(C)CCCC(=O)C2(C)C1</smiles>

(6) Jatamansone<smiles>COC[C]1CC(C)C(O)C(C(C)(C)C)C1</smiles>

(7) lonol 4<smiles>CC1(C)C=CC(=O)C2C1C1CCC2(C)C1(C)C</smiles>

(8) 2, 7, 7-Tetramethyltricyclo2,

[6,2,1,0(1,6)] undec-4-en-3-one

(9) Epiglobulol

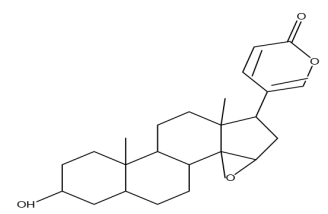

(10) Resibufogenin

Figure 1: Molecular Structures of Volatile Constituents of Nardostachys jatamansi (Rhizomes).

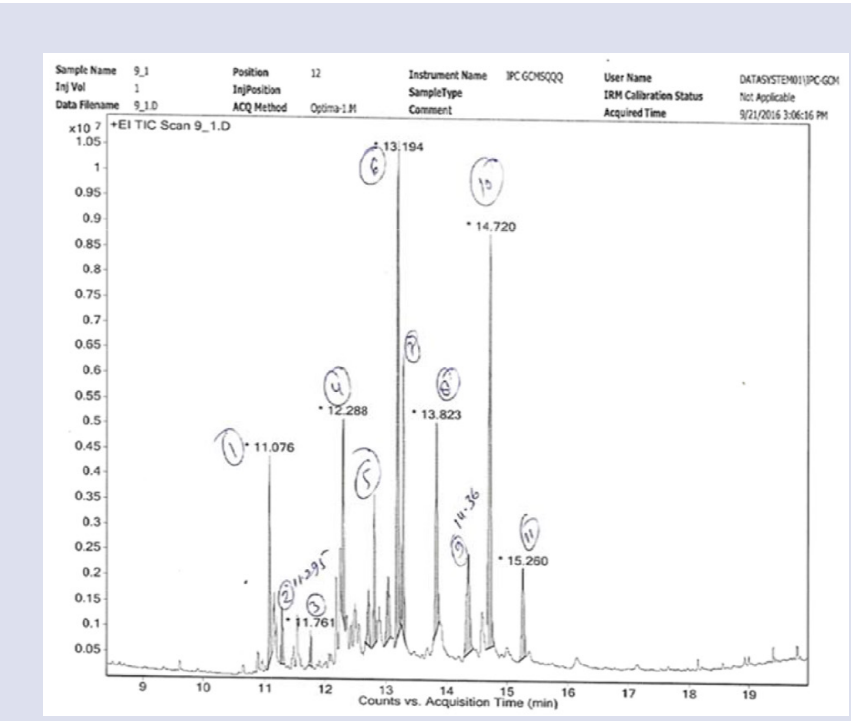

Figure 2: GC-MS Spectra of Nardostachys jatamansi Volatile oil.
Table 1: Chemical composition of volatile constituents of Nardostachys jatamansi Rhizomes.

\begin{tabular}{cccc}
\hline S.No & Name of Vol. constituent & $\begin{array}{c}\text { Percentage } \\
(\%)\end{array}$ & $\begin{array}{c}\text { Retention Index } \\
\text { (RI) }\end{array}$ \\
\hline 1 & Calarene & 20.4 & 1430 \\
2 & Varidiflorene & 12.3 & 1448 \\
3 & $\alpha$-Panasinsen & 9.7 & 1455 \\
4 & a-Santalene & 4.6 & 1485 \\
5 & $\gamma$-Himachalene & 17.1 & 1520 \\
6 & Jatamansone & 7.0 & 1550 \\
7 & Epiglobulol & 1.9 & 1567 \\
8 & Resibufogenin & 8.4 & - \\
9 & Ionol 4 & 9.9 & - \\
10 & 2,2,7,7-Tetramethyltricyclo & 1.7 & - \\
\multicolumn{4}{r}{} \\
\hline
\end{tabular}

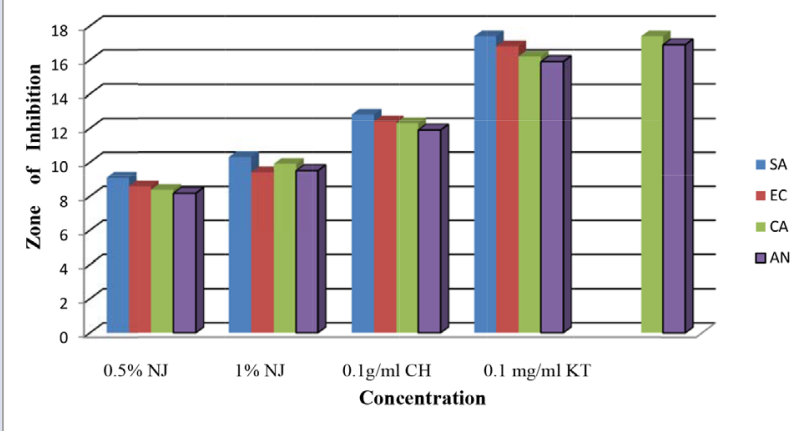

Figure 3: Antimicrobial activity of Nardostachys jatamansi volatile oil.

SA means Staphylococcus aureus

EC means Escherichia coli

CA means Candida albicans

AN means Asperigillus Niger

NJ means Nardostachys jatamansi

CH means Chloramphenicol

KT means Ketoconazole

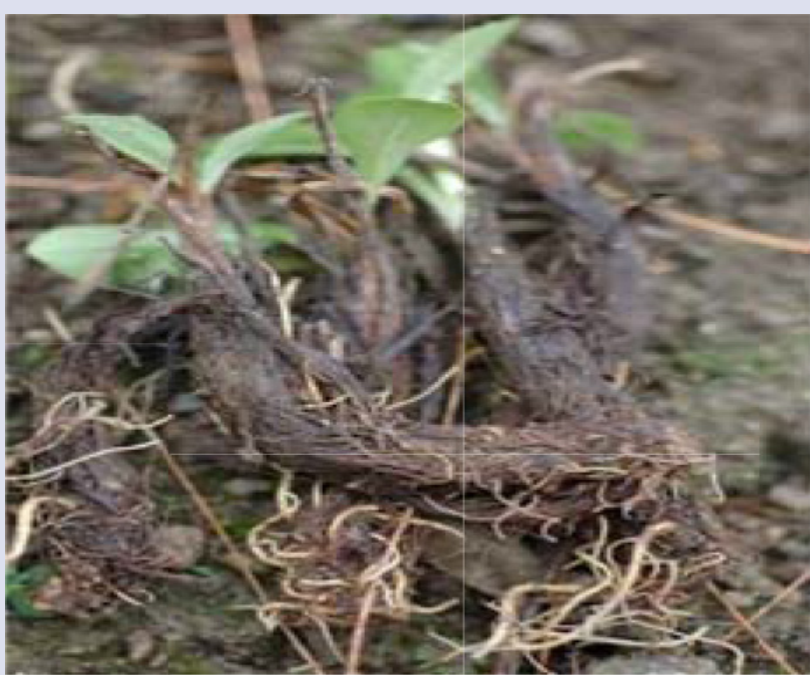

Figure 4: Nardostachys jatamansi roots and Rhizomes. 
Table 2: Mass fragmentation analysis of volatile constituents of Nardostachys jatamansi Rhizomes.

\begin{tabular}{|c|c|c|c|}
\hline S. No & Name/ Mol. For./ Mol. Wt. & $\begin{array}{l}\text { Molecular } \\
\text { Structures }\end{array}$ & Mass Fragmentation Index \\
\hline 1 & $\begin{array}{l}\text { Calarene } \\
\mathrm{C}_{15} \mathrm{H}_{24} \\
204\end{array}$ & (1) & $\begin{array}{c}\text { 161(99.9\%), } 41(31.7 \%), 105(30.5 \%), 91(27.9 \%), 119(24.6 \%) \\
93(22.4 \%), 107(21.2 \%), 162(21.2 \%)\end{array}$ \\
\hline 2 & $\begin{array}{l}\text { Varidiflorene } \\
\qquad \mathrm{C}_{15} \mathrm{H}_{24} \\
204\end{array}$ & (2) & $\begin{array}{c}107(99.9 \%), 105(84.7 \%), 135(81.2 \%), 93(77.6 \%), 161(77 \%) \\
41(69.7 \%), 91(53.85), 81(51.3 \%)\end{array}$ \\
\hline 3 & $\begin{array}{l}\text { a-Panasinsen } \\
\mathrm{C}_{15} \mathrm{H}_{24} \\
204\end{array}$ & (3) & $\begin{array}{c}122(99.9 \%), 107(73.9 \%), 161(73.7 \%), 41(31.7 \%), 105(28 \%), \\
91(24 \%), 55(17.1 \%), 93(15.9 \%)\end{array}$ \\
\hline 4 & $\begin{array}{l}\alpha \text {-Santalene } \\
\mathrm{C}_{15} \mathrm{H}_{24} \\
204\end{array}$ & (4) & $\begin{array}{c}\text { 94(99.9\%), } 41(89.9 \%), 93(89.2 \%), 91(44.7 \%), 95(42.3 \%) \\
107(35.9 \%), 79(35.85 \%), 77(30.6 \%)\end{array}$ \\
\hline 6 & $\begin{array}{l}\text { Jatamansone } \\
\mathrm{C}_{15} \mathrm{H}_{26} \mathrm{O} \\
222\end{array}$ & (6) & $\begin{array}{c}\text { 98(99.9\%), 41(84\%), } 125(79 \%), 69(67 \%), 55(64 \%), 95(62 \%) \\
43(55 \%), 67(53 \%)\end{array}$ \\
\hline 7 & $\begin{array}{c}\text { Ionol } 4 \\
\mathrm{C}_{16} \mathrm{H}_{26} \mathrm{O}_{2} \\
250\end{array}$ & (7) & $\begin{array}{c}\text { 235(99.9\%), } 45(56.1 \%), 250(29.4 \%), 57(27.6 \%), 219(21.7 \%) \\
161(19.8 \%), 91(17.6 \%), 236(16.1 \%)\end{array}$ \\
\hline 8 & $\begin{array}{l}\text { 2,2,7,7-Tetramethyltricyclo }[6,2,1,0(1,6)] \text { undec-4-en-3-one } \\
\qquad \begin{array}{c}\mathrm{C}_{15} \mathrm{H}_{22} \mathrm{O} \\
218\end{array}\end{array}$ & (8) & $\begin{array}{c}175(99.9 \%), 162(79.1 \%), 147(59.8 \%), 218(55.7 \%), 176(55.5 \%), \\
161(52.6 \%), 91(50.3 \%), 41(47.5 \%)\end{array}$ \\
\hline
\end{tabular}

Table 3: Antimicrobial activity of various concentrations of Nardostachys jatamansi volatile oil.

\begin{tabular}{|c|c|c|c|c|c|c|}
\hline \multirow[b]{2}{*}{ S.NO. } & \multirow[b]{2}{*}{ TEST ORGANISM } & & \multicolumn{4}{|c|}{ ZONE OF INHIBITION (mm) } \\
\hline & & $0.1 \% \mathrm{NJ}$ & $0.5 \% \mathrm{NJ}$ & $1 \% \mathrm{NJ}$ & $\begin{array}{l}\text { Chloramphenicol } \\
(0.1 \mathrm{mg} / \mathrm{ml})\end{array}$ & $\begin{array}{c}\text { Ketoconazole } \\
(0.1 \mathrm{mg} / \mathrm{ml})\end{array}$ \\
\hline & Staphylococcus auret & & & & & \\
\hline \multirow[t]{2}{*}{1} & (25923) & $9.1 \pm 0.15$ & $10.3 \pm 0.3$ & $12.8 \pm 0.15$ & $17.4 \pm 0.25$ & $\nabla$ \\
\hline & Escherichia coli & & & & & \\
\hline 2 & (25922) & $8.6 \pm 0.26$ & $9.4 \pm 0.2$ & $12.4 \pm 0.17$ & $16.8 \pm 0.30$ & $\nabla$ \\
\hline \multirow[t]{2}{*}{3} & $\begin{array}{l}\text { Candida albicans } \\
\qquad(10231)\end{array}$ & $8.4 \pm 0.15$ & $9.9 \pm 0.3$ & $12.3 \pm 0.43$ & $16.2 \pm 0.30$ & $17.4 \pm 0.3$ \\
\hline & Asperigillus Niger & & & & & \\
\hline 4 & (16404) & $8.2 \pm 0.2$ & $9.5 \pm 0.32$ & $11.9 \pm 0.15$ & $15.9 \pm 0.26$ & $16.9 \pm 0.37$ \\
\hline
\end{tabular}

${ }^{\star}$ Triplicate Mean \pm SEM is taken $(\mathrm{n}=3)$. 
activity was shown by $1 \%$ v/v of volatile oil on Candida albicans (12.3 $\mathrm{mm}$ ) followed by Aspergillus niger (11.9 mm).

\section{CONCLUSION}

The present study involves identication of total ten volatile constituents. The antibacterial activity shows the highest activity for $1 \% \mathrm{v} / \mathrm{v}$ concentration against Staphylococcus aureus and minimal towards Escherichia coli. While maximum antifungal activity was observed with $1 \% \mathrm{v} / \mathrm{v}$ concentration for Candida albicans and minimum for Aspergillus niger. Further study is required to isolate, identify and elucidate structures of these compounds.

\section{ACKNOWLEDGEMENT}

The Authors are thankful to Sh. P.K.Gupta, Chancellor and Sh. Y.K. Gupta Pro-Chancellor, Sharda University for their support. The Authors are also thankful to Dr. Robin Kumar, Principal Scientific Officer Indian Pharmacopoeial Commission, Ghaziabad for GC and GC-MS analysis.

\section{CONFLICTS OF INTEREST}

The authors declare no conflicts of interest.

\section{ABBREVIATIONS USED}

mm: mili meter; GC MS: Gas Chromatography Mass Spectroscopy; cm: centi meter; m: meter; g: Gram; $\mathbf{0 C}$ : centigrade; $\boldsymbol{\mu l}$ : micro liter; $\mu \mathrm{m}$ : micro meter; DMSO: Dimethyl sulfoxide.

\section{REFERENCES}

1. Wealth of India: A Dictionary of Indian Raw Material and Industrial Products, Publication and Information Directorate, New Delhi. 2001;(4):190-91.

2. Nadkarni KM In: The Indian material Medica. Popular prakashan Private Limited, India.1976;840-42.

3. Chopra RN, Nayar SL, Chopra IC: Glossary of Indian Medicinal Plants, C.S.I.R. New Delhi. 2002;173-74

4. Rastogi RP, Mehrotra BN. Compendium of Indian Medicinal Plants, C. D. R. I,
Lucknow and N I S C AI R, New Delhi. 2005;126-8.

5. Sharma PC, Yelne MB, Dennis TJ. Database on Medicinal plants used in Ayurveda, C C R A S, Deptt. Of ISMSH, Ministry of Health and Family Welfare, New-Delhi. 2002;(7):135-57.

6. Singh V, Ali M. New phytoconstituents from Nardostachys jatamansi Rhizomes J. Saudi Chem.Soc. 2003;7:119-28.

7. Vijender S, Ali Mohd. Volatile Constituents of the Rhizomes of Nardostachys jatamansi DC. Journal of Essential oil bearing plants. 2002;5(2):83-89.

8. Hoerster H, Ruecker G, Tautges J. Valeranone content in the roots of Nardostachys jatamansiand Valeriana officinalis. Phytochem1. 1977;16(7):1070-1.

9. Parveen Z, Siddique S, Shafique M, Shaista JK, Razia K. Volatile constituents, antibacterial and antioxidant activities of Essential Oil from Nardostachys jatamansi DC. Roots. Pharmacology online. 2011;3:329-37.

10. Ahmad A, Munawar Z. Pharmacological importance of Nardostachys jatamansi DC: A potential therapeutic agent in different pathological ailments. Journal of Chemical and Pharmaceutical Research. 2013;5(10):431-8.

11. Mishra D, Chaturvedi RV, Tripathi SC. The fungitoxic effect of the essential oil of Nardostachys jatamansi DC. Trop. Argic. 1995;2(1):48-52.

12. Chao SC, Young DG. Screening for inhibitory activity of essential oils on selected bacteria, fungi and viruses. J. Essent. Oil Res. 2000;12(5):639-49.

13. British Pharmacopoeia, MHRA: London. 2009;92(2):282-3.

14. Jennings W, ShibamooT. Qualitative Analysis of Flavour and Fragrance Volatiles by Capillary Gas Chromatography, Academic Press, New York. 1980.

15. Swigar A, Silverstein RM. Monoterpenes, Aldrich Chem. Co., Milwakee WI. 1981:142

16. Adams RP. Identification of Essential Oil components by Gas Chromatography/ Mass spectrometry, Allured publications Corp. Curol Steane, IL. 1995.

17. Libey LM. A paradox database for GC/MS data components of essential oil and other volatiles. J. Essent. Oils. Res. 1991;3(3):193-4.

18. Vermin G, Petitjean M. The Chemistry of Heterocyclic Flavoring and Aroma Compound, Ellis Horwood, Chichester. 1983;305:70-4.

19. Anderson NH. Falcone MS. The Identification of sesquiterpenes hydrocarbons from GLC retention data. J Chromatography. 1969;44:52-59.

20. Ali M, Techniques in Terpenoid Identification, Birla Publishers, New Delhi. 2001.

21. Pharmacopoeia of India. Controller of Publication, Ministry of Health and Family Welfare, Govt. of India, New Delhi. 1996;(2):A-105

22. Mackie W, Castney MC, Practical Medical BL, Stone CL, Edinburg. London $1989 ; 162$

23. Vijender S, Ali Mohd, Ali Nasir. Antimicrobial activities of Diospyros moristava roxb leaves. Indian Journal of Natural Products. 2005;21(2):30.

\section{GRAPHICAL ABSTRACT}

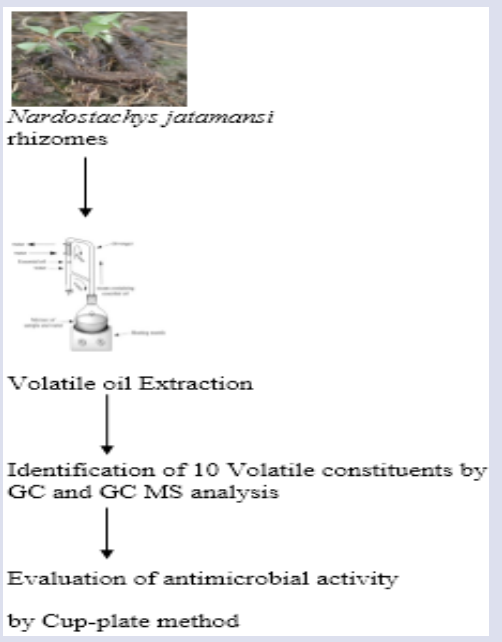

\section{SUMMARY}

- Collection and authentification of rhizomes

- Extraction of Volatile oil by Clevenger's apparatus

- $\quad \mathrm{GC}$ and GC MS analysis of Volatile oil

- Identification of 10 volatile constituents

- Evaluation of antimicrobial activity

Cite this article: Singh V, Rana N, Ali M. GC-MS Analysis and Anti-Microbial Activities of Volatile Oil of Nardostachys jatamansi D.C. Rhizomes Obtained from Haridwar Region, Uttrakhand. Pharmacog J. 2018;10(2):230-4. 